\title{
Korelasi Gaya Kepemimpinan Kepala Madrasah Dan Motivasi Kerja Guru Terhadap Kinerja Guru Di Madrasah Aliyah Negeri 3 Nganjuk
}

\author{
Solikatun', Uswatun Hasanah ${ }^{2}$ \\ ${ }_{1}^{1}$ Pascasarjana Institut Agama Islam Tribakti Kediri, ${ }^{2}$ Institut Agama Islam Tribakti Kediri \\ 1robbiulhuda43@gmail.com, 2uswah@iai-tribakti.ac.id
}

\begin{abstract}
As educators, teachers must be able to improve their performance in carrying out tasks. To achieve high teacher performance, one of them is the motivation factor. Motivation is the driving force for someone to do an activity that is manifested in the form of a real action. Thus the higher the motivation of someone, the higher the performance and vice versa, the lower the motivation of a person, the lower the performance. The success of teacher performance will be seen if there is motivation from the teacher himself and has the support of the madrasa headmaster. Therefore, in addition to the teacher himself who is trying to improve the quality of his performance, the madrasa also seeks to establish good leadership as an empowerment of teachers and madrasa members so that they have good performance in carrying out their duties. This type of research is quantitative research that aims to find answers about the questions in the research based on the actual situation so that it is obtained about the prevailing picture in relation to the correlation between the leadership style of madrasah leaders and teacher work motivation on teacher performance in MAN 3 Nganjuk. The conclusions based on data analysis are: Madrasah headship leadership and teacher work motivation together have positive and significant influence on teacher performance. Good madrasah head leadership and high teacher work motivation will make teachers increasingly improve performance in carrying out their duties.
\end{abstract}

Keywords: Principal Leadership Style, Work Motivation and Teacher Performance.

Abstrak
Sebagai tenaga pendidik, guru harus dapat meningkatkan kinerjanya dalam
melaksanakan tugas. Untuk mencapai kinerja guru yang tinggi salah satunya
diperlukan faktor adanya motivasi. Motivasi merupakan kekuatan
pendorong bagi seseorang untuk melakukan suatu kegiatan yang
diwujudkan dalam bentuk perbuatan nyata. Dengan demikian semakin tinggi
motivasi seseorang maka semakin tinggi pula kinerjanya begitu pula
sebaliknya, semakin rendah motivasi seseorang maka semakin rendah pula
kinerjanya. Keberhasilan kinerja guru akan tampak apabila ada motivasi dari
guru sendiri dan mendapat dukungan dari kepala madrasah. Oleh karena itu,
selain guru sendiri yang berusaha meningkatkan kualitas kinerjanya, pihak
madrasah juga berusaha mengupayakan pembentukan kepemimpinan yang
baik sebagai pemberdayaan guru serta anggota madrasah agar memiliki


kinerja yang baik dalam menjalankan tugasnya. Jenis penelitian ini adalah penelitian kuantitatif yang bertujuan untuk mencari jawaban tentang pertanyaan-pertanyaan dalam penelitian berdasarkan keadaan sebenarnya sehingga diperoleh tentang gambaran yang berlaku dalam kaitannya dengan korelasi gaya kepemimpinan kepala madrasah dan motivasi kerja guru terhadap kinerja guru di MAN 3 Nganjuk. Kesimpulan berdasarkan analisis data adalah: Kepemimpinan kepala madrasah dan motivasi kerja guru secara bersama-sama berpengarauh positif dan signifikan terhadap kinerja guru. Kepemimpinan kepala madrasah yang baik dan motivasi kerja guru yang tinggi akan membuat guru semakin meningkatkan kinerja dalam menjalankan tugasnya.

Kata Kunci: Gaya Kepemimpinan Kepala Madrasah, Motivasi Kerja dan Kinerja Guru.

\section{Pendahuluan}

Guru menjadi salah satu unsur sumber daya yang sangat menentukan keberhasilan dalam pendidikan di sekolah, karena guru merupakan unsur manusiawi yang sangat dekat dengan peserta didik dalam pendidikan seharihari di sekolah. Depdiknas menyatakan bahwa guru merupakan sumberdaya manusia yang mampu mendayagunakan faktor-faktor lainnya sehingga tercipta proses belajar mengajar yang bermutu dan menjadi faktor utama yang menentukan mutu pendidikan. ${ }^{1}$

Dalam pelaksanaan tugas mendidik, guru memiliki sifat dan perilaku yang berbeda, ada yang bersemangat dan penuh tanggung jawab, juga ada guru yang dalam melakukan pekerjaan itu tanpa dilandasi rasa tanggung jawab, selain itu juga ada guru yang sering membolos, datang tidak tepat pada waktunya dan tidak mematuhi perintah.

1 Depdiknas RI. UURJ No. 20. Sistem
Kondisi guru seperti itulah yang menjadi permasalahan di setiap lembaga pendidikan formal. Dengan adanya guru yang mempunyai kinerja rendah, madrasah akan sulit untuk mencapai hasil seperti yang diharapkan. Sebagai tenaga pendidik guru menjadi faktor penentu dalam peningkatan mutu pendidikan di sekolah. Oleh karena itu, para pendidik (guru) harus dapat meningkatkan kinerja dalam melaksanakan tugas karena pendidikan di masa yang akan datang dengan menuntut keterampilan profesi pendidikan yang bermutu. Sehingga kinerja guru yang profesioanal dapat menjadi angin segar bagi keberhasilan dalam dunia pendidikan di masa yang akan datang.

Kinerja guru adalah kemampuan seorang guru dalam melaksanakan proses pembelajaran di kelas sesuai dengan tujuan yang telah ditetapkan. Dimana kemampuan tersebut telah

Jakarta, Diknas, Alat Penilaian Kemampuan Guru, 2003,5 . 
mencakup beberapa aspek, diantaranya: perencanaan program belajar mengajar, pelaksanaan proses belajar mengajar, penciptaan dan pemeliharaan kelas yang optimal, pengendalian kondisi belajar yang optimal, serta penilaian hasil belajar. ${ }^{2}$ Kinerja tentu menjadi faktor yang sangat penting dalam menentukan kualitas kerja seseorang termasuk seorang guru.

Untuk meningkatkan kinerja guru di sekolah pemberian berbagai jenis pelatihan dan pendidikan profesi kepada para guru tentu sangat dibutuhkan. Menurut Taufik (dalam Abdul Hadis dan Nurhayati) menjelaskan ada dua faktor penting yang mempengaruhi kinerja guru di sekolah yaitu faktor kualifikasi standar guru dan relevansi antara bidang keahlian guru dengan tugas mengajar. ${ }^{3}$ Kemudian menurut Mathis dan Robert L. Jackson banyak faktor yang mempengaruhi kinerja dari individu tenaga kerja, antara lain : 1) kemampuan, 2) motivasi, 3) dukungan yang diterima, 4) keberadaan pekerjaan yang mereka lakukan dan 5) hubungan mereka dengan organisasi. ${ }^{4}$

Untuk mencapai kinerja guru yang tinggi salah satunya diperlukan faktor adanya motivasi dari guru untuk meningkatkan kinerjanya secara utuh, Seorang guru harus menunjukkan perilaku yang kuat yang diarahkan untuk menuju suatu tujuan tertentu, adanya

2 Sumarno. Pengaruh Kepemimpinan Kepala Sekolah dan Profesionalisme Guru Terhadap Kinerja Guru Sekolah Dasar Negeri di Kecamatan Paguyangan Kabupaten Brebes. Tesis. (Semarang: Universitas Negeri Semarang, 2009), h. 8. keinginan dan hasrat yang lebih mengarah pada tingkah laku yang berorientasi pada tercapainya standar of excellent. Orientasi tersebut mengarah pada peran guru yang sering kali diposisikan sebagai faktor penting untuk bersikap dan bertindak sesuai dengan profesi. Guru sangat memerlukan adanya semangat dan keinginan yang tinggi untuk mengaktualisasikan potensi yang dimilikinya.

Keberhasilan kinerja akan tampak apabila terdapat motivasi dari kepala Madrasah dan lingkungan sekitar yang menentukan keberhasilan kinerja guru. Oleh karena itu, selain guru sendiri yang berusaha meningkatkan kualitas kinerjanya, pihak instansi juga berusaha mengupayakan pembentukan kepemimpinan yang produktif sebagai pemberdayaan guru serta anggota madrasah agar memiliki kinerja yang baik dan profesional dalam menjalankan tugasnya.

Gaya kepemimpinan kepala madrasah merupakan salah satu faktor penentu terciptanya iklim madrasah yang kondusif dan kinerja madrasah yang baik. Gaya mengandung makna tanggapan atau reaksi individu yang terwujud dalam sikap, tindakan dan ucapan. Dalam konteks kepemimpinan, gaya dimaknai sebagai proses hubungan antara pimpinan dengan anggota atau staf yang menampilkan sifat-sifat, khas,

${ }^{3}$ Abdul Hadis dan Nurhayati B. Manajemen Mutu Pendidikan. Bandung: Alfabeta, 2010), h. 9.

${ }_{4}$ Mathis, Robert L dan Jackson, John H. Manajemen SDM. (Jakarta: Salemba, Empat, 2002), h. 82. 
watak, ketrampilan, kecenderungan, dan perhatian terhadap individu melalui interaksi. Gaya kepemimpinan yang ditampilkan oleh kepala madrasah merupakan implikasi dari kemampuannya mengelola kecerdasan spritiualnya. ${ }^{5}$

Pemimpin mempengaruhi bawahan, tetapi bawahan juga mempunyai beberapa pengaruh terhadap pemimpin. Sumber pengaruh atau kewibawaan pada pemimpin menurut French dan Raven berasal dari legitimasi, memaksa, penghargaan, keahlian, dan penyesuaian (Legitimate, coercive, reward, expert, referent). Atau secara singkat pengaruh pemimpin terhadap bawahan pada dasarnya seperti yang dikemukakan oleh Amitai Etzione mengalir dari Position dan personal power (kedudukan dan kepribadian seseorang). ${ }^{6}$ Sedangkan pengaruh bawahan terhadap pemimpin disebut kewibawaan tandingan (counter power). Kewibawaan bawahan ini akan membantu sebagai pengendali pemakaian kewibawaan pemimpin.

Kepala Madrasah yang berhasil yaitu apabila mereka memahami keberadaan Madrasah sebagai organisasi yang kompleks dan unik.Serta mampu melaksanakan peranan Kepala Madrasah sebagai seorang yang diberi tanggung jawab untuk memimpin madrasah. Kepala Madrasah adalah seseorang yang menentukan kebijakan madrasah, bahkan

5 Didin Kurniadin dan Imam Machali, Manajemen Pendidikan: Konsep, dan Praktik Pengelolaan Pendidikan (Yogyakarta: Ar-Ruzz Media, 2012), h. 8. bisa dikatakan keberhasilan sekolah adalah keberhasilan Kepala Madrasah. ${ }^{7}$ Kepala Madrasah merupakan orang yang memiliki harapan tinggi bagi para staf dan para siswa.Kepala Madrasah adalah mereka yang banyak mengetahui tugastugas mereka dan mereka menentukan kebijakan bagi sekolah mereka. ${ }^{8}$

Singkat kata, gaya kepemimpinan kepala sekolah/madrasah mempunyai pengaruh yang luar biasa bagi para guru dan staf di lingkungan pendidikan yang ia pimpin. Gaya kepemimpinan yang diterapkan akan memberikan nilai positif bagi motivasi dan kinerja para guru dan staf untuk bekerja sesuai dengan profesi dan bidang keahlian yang dia geluti. Kepala madrasah selalu berupaya mencurahkan kemampuannya dalam menjalankan tugasnya untuk mencapai tujuan. Kemampuan yang harus dimiliki seorang pemimpin dalam hal ini kepala madrasah adalah memiliki kepribadian yang menjadi teladan bagi bawahannya, kemampuan memotivasi, pengambilan keputusan, komunikasi dan pendelegasian wewenang.

Berdasarkan dari hasil supervisi yang dilakukan oleh kepala madrasah terhadap 37 orang guru pada tahun 2019 diperolah bahwa masih banyak guru yang belum mampu mencapai nilai indikator aspek persentase pencapaian kinerja guru dalam pembelajaran.

${ }^{6}$ Wahjosumidjo, Kepemimpinan Kepala Sekolah Tinjauan Teoritik dan Permasalahannya, (Jakarta: Raja Grafindo Persada, 2010), h. 34.

${ }^{7} \mathrm{Ibid}, \mathrm{h} .82$.

8 M. Daryanto, Fungsi dan Tanggung Jawab Kepala Sekolah, (Jakarta: Rineka Cipta, 2001), h. 82. 
Sementara itu dari hasil studi pendahuluan yang telah dilakukan oleh peneliti, bahwa di Madrasah Aliyah Negeri (MAN) 3 Nganjuk peneliti mendapatkan sumber data dari hasil wawancara kepada salah satu guru tentang gaya kepemimpinan yang dimiliki oleh kepala Madrasah yaitu, gaya demokratis dan karismatik, yang tidak melibatkan keputusan tanpa anggota bagian, pemimpin selalu membangun solidaritas, kesamaan, kolegial dan mendelegasikan sikap pegawai dan guru di Madrasah. Kepala Madrasah juga sering memberikan motivasi berupa penghargaan, pembinaan dan pelatihan, dengan pemberian penghargaan ternyata ada sebagian pegawai yang iri karena mau memperoleh hadiah juga, namun sifat iri yang dirasakan adalah iri dalam bentuk positif dimana pegawai tersebut bisa lebih giat dan profesional dalam melaksanakan tugasnya. Adapun mengenai kerjasama tim itu ada yang tidak kompak dan dinamis karena setiap pemikiran yang mereka keluarkan masing-masing memiliki perbedaan seperti soal pekerjaan antara pegawai yang satu dengan yang lain, dan seterusnya. ${ }^{9}$

Dari latar belakang di atas, peneliti tertarik untuk mengambil judul penelitian “Korelasi Gaya Kepemimpi-

9 Supriadi, (52 tahun), Ketua Guru Bimbingan Konseling MAN 3 Nganjuk, Wawancara. Nganjuk, 27 Juli 2019.

10 M. Iqbal Hasan, Pokok-pokok Materi Metodologi Penelitian dan Aplikasinya (Jakarta: Ghalia Indonesia, 2002), h. 11. nan Kepala Madrasah dan Motivasi Kerja Guru terhadap Kinerja Guru di Madrasah Aliyah Negeri (MAN) 3 Nganjuk" sebagai wilayah penelitian untuk memenuhi tugas akhir studi di program pascasarjana IAI Tribakti Kediri.

\section{Metode}

Jenis penelitian dikategorikan penelitian lapangan (field research) yaitu penelitian yang dilakukan di kancah atau medan terjadinya gejala. ${ }^{10}$ Penelitian ini menggunakan metode korelasi yaitu metode dengan menghubungkan antara variabel yang dipilih dan dijelaskan dan bertujuan untuk meneliti sejauh mana variabel pada suatu faktor berkaitan dengan variabel yang lain. ${ }^{11}$ Adapun pendekatan yang digunakan dalam penelitian ini adalah pendekatan kuantitatif yang menekankan pada datadata nemerikal (angka-angka) yang diolah dengan metode statistika. ${ }^{12}$

Berdasarkan pemaparan diatas dapat disimpulkan bahwa rancangan penelitian ini dikategorikan penelitian lapangan pada tempat objek penelitian menggunakan metode korelasi antar variabel yang dipilih terhadap variabel lainnya dengan pendekatan kuantitatif yang menekankan pada data numerikal yang diolah melalui statistika sehingga dapat menjelaskan hasil analisa dari hasil olahan antar variabel. Penelitian

\footnotetext{
${ }^{11}$ Ibid., h. 23.

12 Syaifudin Azwar, Metode Penelitian (Yogyakarta: Pustaka Pelajar, 2004), h. 5.
} 
kuantitatif dipengaruhi oleh faham positivisme. Metode ini sebagai cara ilmiah/scientific karena telah memenuhi kaidah-kaidah ilmiah yaitu kongkrit/empiris, obyektif, terukur, rasional, dan sistematis. Penelitian yang menggunakan pendekatan kuantitatif dengan menggunakan metode korelasional ini bertujuan untuk mengetahui besarnya hubungan atau korelasi gaya kepemimpinan kepala madrasah dan motivasi kerja terhadap kinerja guru di MAN 3 Nganjuk.

Penelitian ini termasuk jenis penelitian expost facto, yaitu penelitian yang bertujuan untuk menyelidiki peristiwa yang telah terjadi dan kemudian merunut kebelakang untuk mengetahui faktor-faktor yang menyebabkan terjadinya peristiwa tersebut. ${ }^{13}$ Penelitian ini menggunakan metode deskriptif korelasional. Metode ini mendeskripsikan hubungan antar variabel penelitian, yaitu variabel bebas pertama $\left(X_{1}\right)$ tentang gaya kepemimpinan kepala madrasah, variabel bebas kedua $\left(\mathrm{X}_{2}\right)$ yaitu motivasi kerja guru, dan variabel terikat $(\mathrm{Y})$ kinerja guru. ${ }^{14}$

Populasi adalah wilayah generalisasi yang terdiri atas: obyek/subyek yang mempunyai kualitas dan karakteristik tertentu yang ditetapkan oleh peneliti

13 Sugiyono, Metode Penelitian Administrasi (Bandung: Alfabeta, 2014), h. 7.

14 A. Jauhar Fuad and Agus Eko Sujianto, Analisis Statistik Dengan Program SPSS (Tulungagung: Cahaya Abadi, 2014)

15 Sugiyono, Metode Penelitian Pendidikan, (Bandung: Alfabeta, 2013), h. 297. untuk dipelajari dan kemudian ditarik kesimpulannya. ${ }^{15}$ Populasi dalam penelitian ini adalah guru MAN 3 Nganjuk yang berjumlah 37 orang. Sedangkan sampel penelitian ini mengambil seluruh populasi sebagai sampel penelitian (teknik total sampling). Jadi, jumlah sampel dalam penelitian ini adalah 37 orang.

Instrumen penelitian merupakan alat atau fasilitas yang digunakan oleh peneliti dalam pengumpulan data agar peneliti lebih mudah dan hasilnya lebih baik, dalam arti lebih cermat, lengkap dan sistematis sehingga lebih mudah diolah. ${ }^{16}$ Menurut Sugiyono instrumen penelitian adalah suatu alat yang digunakan untuk mengukur fenomena alam maupun sosial yang diamati. ${ }^{17}$ Instrumen yang akan digunakan dalam penelitian ini adalah berupa angket. Untuk mendapatkan data yang konkrit dari lapangan menggunakan instrumen pengumpulan data angket. Angket adalah sejumlah pertanyaan tertulis yang digunakan untuk memperoleh informasi dari responden dalam arti laporan tentang pribadinya atau hal-hal yang diketahui. ${ }^{18}$

16 Suharsimi Arikunto, Prosedur Penelitian: Suatu Pendekatan praktik. (Jakarta: Rineka Cipta, 2006), h. 136.

17 Sugiyono, Metode Penelitian Kuantitatif, Kualitatif, dan Kombinasi (Mixed Methods), Bandung: Alfabeta, 2012), h.148.

18 Suharsimi Arikunto, Prosedur Penelitian: Suatu Pendekatan Praktik (Edisi Revisi). (Jakarta: Rineka Cipta, 2010), h. 151. 


\section{Kajian Teoritik}

\section{Gaya Kepimpinan Kepala Madrasah}

Menurut purwanto gaya kepemimpinan adalah suatu cara atau teknik seseorang dalam menjalankan suatu kepemimpinan. Gaya kepemimpinan dapat pula diartikan sebagai norma perilaku yang digunakan seseorang pada saat orang tersebut mencoba mempengaruhi perilaku orang lain. ${ }^{19}$ Dalam hal ini usaha menselaraskan persepsi diantara orang yang akan mempengaruhi prilaku dengan yang akan dipengaruhi menjadi amat penting kedudukannya.

Berbicara mengenai gaya kepemimpinan yang sesungguhnya berarti berbicara mengenai "moralitas" dalam kepemimpinan. Moralitas berarti caracara yang disenangi dan digunakan oleh seseorang sebagai wahana untuk menjalankan kepemimpinannya. Setiap pemimpin akan mengambil cara tertentu bergantung pada orang yang dipimpinnya, masalah yang dihadapinya, dan situasi yang dirasakannya. Setiap pemimpin memiliki cara yang berbedabeda antara yang satu dengan yang lain dalam memimpin suatu organisasi. Nawawi menyatakan bahwa:

"Gaya kepemimpinan adalah perilaku atau cara yang dipilih dan dipergunakan pemimpin dalam mempengaruhi pikiran, perasaan, sikap dan perilaku para anggota

19 Purwanto, Penerapan Kepemimpinan (Jakarta: Raja Grafindo Persada, 1997), h. 48.

${ }^{20}$ Nawawi, Manajemen Sumber Daya

Manusia: Untuk Bisnis Yang Kompetitif (Gajahmada University, 2011), Yogyakarta Press, h. 42 organisasi atau bawahannya. Seseorang yang menduduki jabatan pimpinan mempunyai kapasitas untuk membaca situasi yang dihadapinya secara tepat dan menyesuaikan gaya kepemimpinanya agar sesuai dengan tuntutan situasi yang dihadapinya, meskipun penyeseuaian ini hanya bersifat sementara". ${ }^{20}$

Rivai menyatakan bahwa:

"Gaya kepemimpinan adalah sekumpulan ciri yang digunakan pimpinan untuk mempengaruhi bawahan agar sasaran organisasi tercapai atau dapat puladikatakan bahwa gaya kepemimpinan adalah pola perilaku dan strategi yang disukai dan sering diterapkan oleh seorang pimpinan". ${ }^{21}$

Sedangkan Menurut Thoha bahwa Gaya kepemimpinan merupakan norma perilaku yang digunakan oleh seseorang pada saat orang tersebut mencoba mempengaruhi perilaku orang lain seperti yang dia lihat. ${ }^{22}$

Bass mengemukakan sebuah teori kepemimpinan transformasional (transformational leadership) yang dibangun atas gagasan dari Burns. Tingkatan seorang pemimpin disebut transformasional terutama diukur dalam hubungannya dengan efek pemimpin tersebut terhadap para pengikutnya. Para pengikut pemimpin transformasional merasakan adanya kepercayaan, kekaguman,

21 Zainal Rivai, Veithzal dkk, Kepemimpinan dan Perilaku Organisasi (Jakarta: Raja Grafindo Persada, 2014), h. 42.

22Toha Miftah, Perilaku Organisasi, Konsep Dasar dan Aplikasinya, (Jakarta: Raja Grafindo Persada, 2013), h. 49. 
kesetiaan dan hormat terhadap pemimpin serta merasa termotivasi untuk melakukan sesuatu yang lebih dari yang diharapkan dari mereka. Pemimpin tersebut mentransformasi dan memotivasi para anggota atau pengikutnya dengan; a) membuat mereka lebih sadar mengenai pentingnya hasilhasil suatu pekerjaan, b) mendorong mereka untuk lebih mementingkan organisasi atau tim dari pada kepentingan diri sendiri, c) mengaktifkan kebutuhan-kebutuhan mereka pada yang lebih tinggi. ${ }^{23}$

Berdasarkan definisi beberapa ahli diatas dapat disimpulkan bahwa gaya kepemimpinan merupakan suatu cara seorang pemimpin untuk mempengaruhi bawahannya agar dapat bekerja sama dan bekerja secara produktif untuk mencapai tujuan organisasi.

Dalam sebuah organisasi terdapat pemimpin yang mengatur wilayah keorganisasiannya, sebagaimana dalam lingkungan pendidikan yang dipimpin oleh kepala sekolah/madrasah. Kepala Madrasah termasuk pemimpin formal dalam lembaga pendidikan, diartikan sebagai kepala madrasah karena kepala madrasah adalah pejabat tertinggi di sekolah. Kepemimpinan memegang peranan penting dalam perkembangan sekolah, jiwa kepemimpinan kepala madrasah dipertaruhkan dalam proses

${ }^{23}$ Tim Dosen Administrasi Pendidikan Universitas Pensisikan Indonesia, Manajemen Pendidikan (Bandung: Alfabeta, 2009), h. 149. pembinaan para guru, pegawai tata usaha, dan pegawai lainnya. ${ }^{24}$

Gaya kepemimpinan kepala madrasah adalah cara atau usaha kepala madrasah dalam mempengaruhi, mendorong, membimbing, mengarahkan dan menggerakkan guru, staf, siswa, orang tua siswa dan pihak terkait untuk bekerja atau berperan guna mencapai tujuan yang ditetapkan. Cara kepala madrasah membuat orang bekerja untuk mencapai tujuan sekolah merupakan inti kepemimpinan kepala madrasah.

Kepemimpinan kepala madrasah adalah perilaku kepala madrasah yang mampu memprakarsai pemikiran baru di dalam proses interaksi di lingkungan sekolah dengan melakukan perubahan atau penyesuaian tujuan, sasaran, konfigurasi, prosedur, input, proses atau output dari suatu sekolah sesuai dengan tuntutan perkembangannya. ${ }^{25}$ Kepemimpinan kepala madrasah adalah sebagai seorang tenaga fungsional guru yang diberi tugas untuk memimpin suatu sekolah dimana diselenggarakan proses belajar mengajar, atau tempat dimana terjadi interaksi antara guru dan siswa. ${ }^{26}$

Berdasarkan pengertian yang dipaparkan oleh para ahli di atas maka dapat penulis simpulkan bahwa gaya kepemimpinan kepala madrasah adalah kepribadian yang diterapkan oleh kepala madrasah dalam kepemimpinannya yang bertujuan untuk mempengaruhi orang

24 Herabudin, Administrasi dan Supervisi Pendidikan, Cet. 1; (Bandung: Pustaka Setia, 2009), h. 202.

${ }^{25}$ Wahjosumidjo, Kepemimpinan..., h. 7.

${ }^{26} \mathrm{Ibid}$. h. 83 
lain demi tercapainya tujuan yang diinginkan bersama sehingga terwujudnya lembaga kualitas pendidikan yang produktif.

\section{Motivasi Kerja Guru}

Menurut Wexley and Yukl yang dikutip oleh Madjid Motivasi kerja adalah "segala sesuatu yang menimbulkan semangat atau dorongan untuk bekerja". Kemudian Robbins dalam Madjid yang dikutip oleh Madjid menyatakan bahwa motivasi merupakan "kesediaan untuk mengeluarkan tingkat upaya yang tinggi ke arah tujuan-tujuan organisasi, yang dikondisikan oleh kemampuan kebutuhan individual".27 Menurut Mathis-Jackson dalam Madjid motivasi adalah "keinginan dalam diri seseorang yang menyebabkan orang tersebut bertindak." Atau dengan kata lain, motivasi merupakan dorongan yang diatur oleh tujuan yang jarang muncul dalam kekosongan. Dessler dalam Madjid menyatakan bahwa "motivasi memberikan umpan balik kepada pegawai untuk menghilangkan penurunan kinerja atau terus bekerja lebih giat". ${ }^{28}$

Motivasi adalah serangkaian sikap dan nilai yang mempengaruhi individu untuk mencapai hal yang spesifik sesuai dengan tujuan individu. Sikap dan nilai tersebut merupakan suatu yang invisible yang memberikan kekuatan untuk mendorong individu bertingkah laku

\footnotetext{
${ }^{27}$ Madjid, Abd., Pengembangan..., h. 62.

28 Ibid., h. 63.

${ }^{29}$ Ibid., h. 64.

${ }^{30}$ Ida Ayu Brahmasari dan Suprayetno, A.,
}

Pengaruh Motivasi Kerja, Kepemimpinan dan Budaya dalam mencapai tujuan. Veithzal dalam Madjid mengemukakan: "Dua hal yang dianggap sebagai dorongan individu yaitu arah prilaku (kerja untuk mencapai tujuan) dan kekuatan prilaku (seberapa kuat usaha individu dalam bekerja)" ${ }^{29}$

Motivasi berasal dari bahasa latin movere yang berarti dorongan atau penggerakan. Secara umum motivasi dapat diartikan sebagai dorongan dan keinginan serta upaya yang muncul dari diri seorang individu untuk melakukan suatu hal. Robbin dalam Brahmasari dan Suprayetno mengemukakan bahwa motivasi adalah keinginan untuk melakukan sebagai kesediaan untuk mengeluarkan tingkat upaya yang tinggi untuk tujuan organisasi, yang dikondisikan oleh kemampuan upaya itu untuk memenuhi suatu kebutuhan individual. ${ }^{30}$

Berdasarkan pendapat para ahli di atas dapat disimpulkan bahwa motivasi adalah suatu dorongan kebutuhan dalam diri pegawai yang perlu dipenuhi agar pegawai tersebut dapat menyesuaikan diri terhadap lingkungannya, sedangkan motivasi kerja adalah kondisi yang dapat menggerakkan pegawai agar mampu mencapai tujuan dari motifnya, serta mendapatkan kepuasan dari hasil kerja yang dicapainya. Dengan kata lain motivasi kerja didefinisikan sebagai kesediaan untuk melakukan upaya yang tinggi untuk mencapai tujuan organisasi

Organisasi Terhadap Kepuasan Kerja Karyawan serta Dampaknya pada Kinerja Perusahaan (Studi Kasus pada PT. Pei Hai International Wiratama Indonesia), Jurnal Manajemen dan Kewirausahaan, 2008, Vol 10, No 2 : 124-135, h. 125. 
yang dikondisikan dengan kemampuan upaya-upaya itu dalam memenuhi beberapa kebutuhan individu. Sementara itu, motivasi secara umum berhubungan dengan tujuan organisasi dengan pendekatan fokus organisasi yang direfleksikan dengan minat yang tunggal berhubungan dengan perilaku.

Motivasi tidak dapat diamati secara langsung, tetapi dapat diinterpretasikan dari tingkah lakunya. Guru dalam melaksanakan tugas dan pekerjaan membutuhkan motivasi kerja baik dari diri sendiri maupun dari luar. Guru akan bersemangat melakukan segala aktivitas ketika dalam dirinya telah ada motivasi kerja yang tinggi, motivasi selalu mengandung pengertian yang sesuai denga apa yang mendasarinya. Motivasi kerja guru berarti sebuah motivasi yang mendasari guru dalam melaksanakan pekerjaan.

Menurut Pupuh Fathurrohman \& Aa Suryana indikator-indikator yang digunakan untuk mengukur motivasi kerja guru meliputi: a) Imbalan yang layak Kepuasan guru menerima imbalan atau gaji yang diberikan lembaga dapat menentukan motivasi kerja. Guru dengan gaji yang tidak sesuai dengan beban kerja yang diberikan membuat motivasi kerja akan menurun. Sebaliknya, guru dengan gaji yang sesuai dan bisa memenuhi kebutuhan hidup akan selalu termotivasi dalam melakukan berbagai pekerjaan. b) Kesempatan untuk promosi Promosi jabatan merupakan salah satu cara untuk dapat meningkatkan motivasi kerja. Banyaknya kesempatan promosi jabatan yang diberikan lembaga kepada guru akan berdampak pada keinginan guru untuk meningkatkan kualitas kerja. c) Memperoleh pengakuan Sebuah pengakuan dari pihak lembaga terhadap kerja yang telah dilaksanakan oleh guru akan memberikan dampak bagi peningkatan motivasi kerja guru. Pekerjaan yang selalu diakui membuat guru selalu memperbaiki dan menyelesaikan tugas lebih baik dari yang sebelumnya. d) Keamanan bekerja Lingkungan kerja yang aman sangat diharapkan oleh semua orang termasuk guru. Lingkungan sekolah yang sesuai dengan standar yang telah ditetapkan dalamperaturan perundang-undangan akan membuat guru mampu bekerja dengan maksimal. ${ }^{31}$

Hamzah B. Uno menyebutkan bahwa indikator motivasi kerja guru tampak melalui: a) Tanggung jawab dalam melakukan kerja.Guru yang memiliki motivasi yang tinggi terlihat dari tanggung jawabnya dalam melakukan pekerjaan. Guru akan menyelesaikan pekerjaan dengan hasil maksimal sesuai dengan batas waktu yang telah ditentukan. Guru akan merencanakan, melaksanakan, dan harus mengevaluasi pembelajaran sesuai peraturan yang berlaku. b) Prestasi yang dicapainya. Prestasi yang diperoleh guru 
memperlihatkan bahwa guru tersebut memiliki motivasi kerja yang tinggi. Prestasi tersebut dapat berupa penghargaan dari kepala sekolah, lembaga pendidikan, maupun karya yang diciptakan) Pengembangan diri. Guru dalam menjalankan profesinya sangat perlu untuk melakukan pengembangan diri. Keikutsertaan guru dalam pelatihan-pelatihan yang diadakan oleh lembaga pendidikan menunjukkan bahwa guru memiliki antusias sehingga tercipta motivasi kerja yang tinggi d) Kemandirian dalam bertindak. Seseorang yang sudah masuk dalam usia produktif tentu memiliki sikap mandiri dalam bertindak. Kemandirian ini tercermin pada sikap guru yang selalu mengerjakan tugas dan tanggungjawabnya meskipun tidak diperintah. Guru secara sadar mengerjakan pekerjaan yang menjadi kewajibannya. ${ }^{32}$

Berdasarkan beberapa pendapat para ahli di atas, dapat disimpulkan bahwa motivasi kerja guru diukur dari dua dimensi, yaitu motivasi internal dan motivasi eksternal. Motivasi internal meliputi tanggungjawab dalam melaksanakan tugas, melaksanakan tugasdengan target yang jelas, kemandirian dalam bertindak, memiliki perasaan senang dalam bekerja, dan prestasi yang dicapai. Motivasi eksternal meliputi berusaha untuk memenuhi

${ }^{32}$ Hamzah B. Uno, Teori Motivasi dan Pengukurannya: Analisis di Bidang pendidikan, (Jakarta: Bumi Aksara, 2013), h. 72.

${ }^{33} \mathrm{Ibid}$., h. 10. kebutuhan, kesempatan untuk promosi, memperoleh pengakuan, dan bekerja dengan harapan memperoleh imbalan yang layak.

\section{Kinerja Guru}

Istilah kinerja dimaksudkan sebagai terjemahan dari istilah "performance". Kinerja bukan merupakan karakteristik seseorang seperti bakat atau kemampuan, tetapi perwujudan dari bakat atau kemampuan itu sendiri. Pendapat tersebut menunjukkan bahwa kinerja merupakan perwujudan dari kemampuan dalam bentuk karya nyata. Kinerja dalam kaitannya dengan jabatan diartikan sebagai hasil yang dicapai yang berkaitan dengan fungsi jabatan dalam periode waktu tertentu. Prestasi kerja (performance) diartikan sebagai suatu pencapaian persyaratan pekerjaan tertentu yang akhirnya secara langsung dapat tercermin dari output yang dihasilkan baik kuantitas maupun mutunya. Kinerja adalah performance atau unjuk kerja. 33 Kinerja dapat pula diartikan prestasi kerja atau pelaksanaan kerja atau hasil unjuk kerja.

Kinerja menurut Menurut Whitmore adalah pelaksanaan fungsi-fungsi yang dituntut dari seseorang. ${ }^{34}$ Kinerja merupakan hasil kerja yang dicapai seseorang dalam melaksanakan tugastugas yang dibebankan kepadanya didasarkan atas kecakapan, pengalaman, kesungguhan dan waktu. ${ }^{35}$ Lebih lanjut,

34 Hamzah B. Uno dan Nina Lamatenggo, Teori..., h. 59.

${ }^{35}$ Hasibuan, Malayu, S.P., Manajemen..., h. 82. 
Hasibuan menggungkapkan bahwa kinerja merupakan gabungan tiga faktor penting yaitu kemampuan dan minat seorang pekerja, kemampuan serta penerimaan atas penjelasan delegasi tugas dan peran serta pekerja. Mangkunegara mengemukakan kinerja dapat didefinisikan sebagai hasil kerja secara kualitas dan kuantitas yang dapat dicapai oleh seorang pegawai dalam melaksanakan tugas sesuai dengan tanggung jawab yang diberikan kepadanya. ${ }^{36}$ Sedangkan menurut Mc Daniel berpendapat bahwa kinerja adalah "interaksi antara kemampuan seseorang dengan motivasinya". ${ }^{37}$

Berdasarkan definisi kinerja yang dikemukakan oleh beberapa ahli di atas, dapat disimpulkan bahwa kinerja adalah hasil kerja atau prestasi yang dicapai oleh seseorang, yang dinilai berdasarkan kualitas dan kuantitasnya sesuai dengan tugas dan tanggung jawab yang dibebankan kepadanya dalam rangka mencapai tujuan bersama. Dengan demikian, kinerja guru berarti adalah hasil yang dicapai oleh guru dalam melaksanakan tugas-tugas dalam pembelajaran yang dibebankan kepadanya yang dilihat melalui kegiatan perencanaan, pelaksanaan, pelaksanaan penilaian, dan tindak lanjut hasil penilaian.

36 Mangkunegara, A.A. Anwar Prabu, Manajemen Sumber Daya Manusia Perusahaan. (Bandung: Remaja Rosdakarya, 2001), h. 32.

37 Hamzah B. Uno dan Nina Lamatenggo,

Teori Kinerja dan Pengukurannya (Jakarta, Bumi Aksara, 2012), h. 62.
Kinerja guru terlihat dari kegiatan sehari-hari di sekolah. Hadir di sekolah tepat waktu, melaksanakan pembelajaran yang kondusif, mengikuti kegiatan di luar tugas utama mengajar, dan selalu meningkatkan profesionalisme. Kegiatan tersebut harus di nilai agardapat menunjukkan kinerja guru yang sudah optimal dan yang belum optimal. Imam Wahyudi menyebutkan bahwa: Ukuran kinerja guru terlihat dari rasa tanggung jawabnya melaksanakan tugas, amanah, profesi yang diembannya, serta tanggung jawab moral di pundaknya. Semua itu akan terlihat dalam kepatuhan dan loyalitasnya dalam menjalankan tugas profesinya di dalam maupun di luar kelas. Guru sebagai profesi akan terikat dengan tanggung jawab untuk melaksanakan tugas yang diembannya. Beratnya beban yang ditanggung oleh guru mengharuskan guru selalu patuh dan loyal dalam menjalankan tugas profesinya di dalam maupun di luar kelas sehingga tercipta kinerja guru yang optimal. ${ }^{38}$

Selanjutnya menurut Mulyasa tujuh indikator yang menunjukkan lemahnya kinerja guru dalam melaksanakan tugas utamanya (teaching), yaitu:1) Rendahnya pemahaman tentang strategi pembelajaran, 2) Kurangnya kemahiran dalam mengelola kelas, 3) Rendahnya kemampuan melakukan dan memanfaat-

${ }^{38}$ Imam

Wahyudi,

Mengejar

Profesionalisme Guru, (Jakarta: Prestasi Pustaka, 2012), h. 87. 
kan penelitian tindakan kelas (classroom asction research), 4) Rendahnya motivasi berprestasi, 5) Kurang disiplin, 6) Rendahnya komitmen profesi, 7) Rendahnya kemampuan manajemen waktu. Kinerja guru akan tidak optimal apabila guru tidak memahami strategipembelajaran yang baik, tidak mampu mengelola kelas, tidak disiplin,dan tidak meningkatkan profesionalismenya. ${ }^{39}$

Menurut Supardi, "untuk mengungkap dan mengukur kinerja guru dapat dilakukan dengan menelaah kemampuan dasar guru atau pelaksanaan kompetensi dasar guru atau motivasinya dalam bekerja". Kemampuan dasar dan motivasi merupakan dua hal yang sangat menentukan kinerja seseorang. Kinerja guru dapat diamati dari kemampuan dasar guru, yaitu kompetensi pedagogik, kompetensi profesional, kompetensi kepribadian, dan kompetensi sosial. Apabila keempat kompetensi tersebut baik maka kinerja gurupun akan baik. Selain itu, kinerja guru juga dapat diamati dari motivasinya dalam bekerja. Guru yang semangat dalam bekerja, tidak mudah menyerah, dan selalu menyelesaikan tugas dengan sempurna sesuai tujuan yang telah ditetapkan maka kinerja guru tersebut sangatlah optimal. ${ }^{40}$

Berdasarkan beberapa pendapat di atas dapat disimpulkan bahwa kinerja guru merupakan hasil kerja yang dapat dicapai guru dalam suatu organisasi (sekolah), sesuai dengan wewenang dan tanggung jawab yang diberikan sekolah dalam upaya mencapai visi, misi, dan tujuan sekolah bersangkutan secara legal, tidak melanggar hukum dan sesuai dengan moral maupun etika. Kinerja guru nampak dari tanggung jawabnya dalam menjalankan amanah, profesi yang diembannya, serta moral yang dimilikinya. Singkatnya kinerja guru merupakan hasil kerja guru yang diwujudkan dalam bentuk pengetahuan, keterampilan, nilai dan sikap guru dalam melaksanakan tugas dan fungsinya, yang ditunjukkan dalam penampilan, perbuatan, dan prestasi kerjanya.

\section{Pembahasan}

Korelasi pada gaya kepemimpinan kepala madrasah terhadap kinerja guru

Variabel Gaya Kepemimpinan Kepala Madrasah $\left(X_{1}\right)$ dan Kinerja Guru (Y) nilai Sig. (2-tailed) sebesar 0,262, kemudian dibandingkan dengan nilai probabilitas 0,05, ternyata nilai taraf Sig. (2-tailed) lebih besar dari pada nilai probabilitas 0,05 atau $[0,262>0,05]$, maka Ho ditolak dan Ha diterima artinya Signifikan, sehingga dapat disimpulkan bahwa variabel gaya kepemimpinan kepala madrasah $\left(\mathrm{X}_{1}\right)$ berhubungan secara signifikan terhadap variabel Kinerja Guru (Y).

40 Supardi, Kinerja Guru (Jakarta: Rajagrafindo Persada, 2013), h. 48. 
Korelasi pada motivasi kerja guru terhadap kinerja guru

Variabel motivasi kerja $\left(\mathrm{X}_{2}\right)$ dan Kinerja Guru (Y) nilai Sig. (2-tailed) sebesar 0,193, kemudian dibandingkan dengan nilai probabilitas 0,05 , ternyata nilai taraf Sig. (2-tailed) lebih besar dari pada nilai probabilitas 0,05 atau $[0,193>$ 0,05], maka Ho ditolak dan Ha diterima artinya Signifikan, sehingga dapat disimpulkan bahwa variabel motivasi kerja (X2) berhubungan secara signifikan terhadap variabel kinerja guru $(\mathrm{Y})$.

Korelasi secara simultan antara gaya kepemimpinan kepala madrasah dan motivasi kerja guru terhadap kinerja guru

Diperoleh pada nilai $F=0,840$ dengan tingkat probabilitas Sig. 0,441. Oleh karena probabilitas $(0,441)$ lebih besar dari pada 0,05, maka dengan demikian dapat disimpulkan bahwa model regresi ganda sangat signifikan dapat dipakai untuk memprediksi korelasi antara variabel $\mathrm{X} 1, \mathrm{X} 2$ dan $\mathrm{Y}$.

Hasil uji-t (Student) pada variabel gaya kepemimpinan kepala madrasah $\left(X_{1}\right)$ terhadap kinerja guru $(Y)$. Hasil analisis tabel Coefficients ${ }^{a}$ diperoleh bahwa nilai $X_{1}$ pada $t_{\text {hitung }}=3,140$. Ternyata nilai $t_{\text {hitung }}>t_{\text {tabel, }}$ atau 3,140 $>$ 2,042, maka Ho ditolak dan Ha diterima, artinya signifikan. Jadi, Terdapat korelasi yang signifikan antara gaya kepemimpinan kepala madrasah terhadap kinerja guru MAN 3 Nganjuk.

Hasil uji-t (Student) pada variabel motivasi kerja terhadap kinerja guru. analisis tabel Coefficients ${ }^{a}$ diperoleh $\sim$ bahwa nilai $X_{2}$ pada $t_{\text {hitung }}=2.401$.
2,042, maka Ho ditolak dan Ha diterima, artinya signifikan. Jadi, Terdapat korelasi yang signifikan antara motivasi kerja terhadap kinerja guru MAN 3 Nganjuk.

Berdasar analisis di atas maka dapat disimpulkan bahwa: ada hubungan positif dan signifikan antara variabel gaya kepemimpinan kepala madrasah $\left(\mathrm{X}_{1}\right)$, dan motivasi kerja guru $\left(X_{2}\right)$ secara parsial atau sendiri-sendiri terhadap variabel kinerja guru $(Y)$.

\section{Kesimpulan}

Berdasarkan rumusan masalah dan hasil-hasil penelitian, maka penelitian ini dapat disimpulkan berikut:

1. Terdapat korelasi antara gaya kepemimpinan kepala madrasah terhadap kinerja guru MAN 3 Nganjuk. Diketahui bahwa nilai Sig. (2-tailed) sebesar 0,262, kemudian dibandingkan dengan nilai probabilitas 0,05 , ternyata nilai taraf Sig. (2-tailed) lebih besar dari pada nilai probabilitas 0,05 atau $[0,262>$ $0,05]$.

2. Terdapat korelasi antara motivasi kerja guru terhadap kinerja guru MAN 3 Nganjuk. Nilai Sig. (2-tailed) sebesar 0,193, kemudian dibandingkan dengan nilai probabilitas 0,05 , ternyata nilai taraf Sig. (2-tailed) lebih besar dari pada nilai probabilitas 0,05 atau $[0,193>$ $0,05]$.

3. Terdapat secara simultan antara gaya kepemimpinan kepala madrasah dan motivasi kerja guru terhadap kinerja guru MAN 3 Nganjuk. Nilai $F=0,840$ 
dengan tingkat probabilitas Sig. 0,441. Oleh karena probabilitas $(0,441)$ lebih besar dari pada 0,05 , maka dengan demikian dapat disimpulkan bahwa model regresi ganda sangat signifikan dapat dipakai untuk memprediksi korelasi antara variabel $\mathrm{X} 1, \mathrm{X} 2$ dan $\mathrm{Y}$. Nilai $X_{1}$ pada $t_{\text {hitung }}=3,140$. Ternyata nilai $t_{\text {hitung }}>t_{\text {tabel, }}$, atau $[3,140>2,042]$, maka Ho ditolak dan Ha diterima, artinya signifikan. Nilai $\mathrm{X}_{2}$ pada $t_{\text {hitung }}$ $=2.401$. Ternyata nilai $t_{\text {hitung }}>t_{\text {tabel, }}$ atau $[2.401>2,042]$.

\section{Daftar Pustaka}

Arikunto, Suharsimi. Prosedur Penelitian: Suatu Pendekatan Praktik (Edisi Revisi). Jakarta: Rineka Cipta, 2010.

Azwar, Syaifudin. Metode Penelitian. Yogyakarta: Pustaka Pelajar, 2004.

Brahmasari, I. A. dan Suprayetno, A. Pengaruh Motivasi Kerja, Kepemimpinan dan Budaya Organisasi Terhadap Kepuasan Kerja Karyawan serta Dampaknya pada Kinerja Perusahaan (Studi Kasus pada PT. Pei Hai International Wiratama Indonesia).Jurnal Manajemen dan Kewirausahaan, Vol 10, No 2 : 124135, 2008.

Daryanto, M. Fungsi dan Tanggung Jawab Kepala Sekolah, Jakarta: Rineka Cipta, 2001.

Depdiknas RI. UURJ No. 20. Sistem Pendidikan Nasional Jakarta: Depdiknas RI Jakarta, Diknas, Alat Penilaian Kemampuan Guru, 2003.
Didin Kurniadin dan Imam Machali, Manajemen Pendidikan: Konsep, dan Praktik Pengelolaan Pendidikan, Yogyakarta: Ar-Ruzz Media, 2012.

Fathurrohman, Pupuh \&Aa Suryana, Guru Profesional, Bandung: Refika Aditama, 2012.

Fuad A. Jauhar, and Agus Eko Sujianto, Analisis Statistik Dengan Program SPSS (Tulungagung: Cahaya Abadi, 2014)

Hamzah B. Uno dan Nina Lamatenggo, Teori Kinerja dan Pengukurannya. Jakarta, Bumi Aksara, 2012.

Hasan, Iqbal M. Pokok-pokok Materi Statistik 1 (Statistik Deskriptif). Jakarta: Bumi Aksara, 2009.

Herabudin, Administrasi dan Supervisi Pendidikan, Cet. 1; Bandung: Pustaka Setia, 2009.

Mathis, Robert L dan Jackson, John H. Manajemen SDM. Jakarta: Salemba, Empat, 2002.

Miftah, Thoha, Perilaku Organisasi Konsep Dasar dan Aplikasi, Jakarta: Raja Grafindo Persada, 2004.

Mangkunegara, A.A. Anwar Prabu, Manajemen Sumber Daya Manusia Perusahaan. Bandung: Remaja Rosdakarya, 2001

Mulyasa, E. Uji Kompetensi dan Penilaian Kinerja Guru. Bandung: Remaja Rosdakarya, 2013.

Nawawi. Manajemen Sumber Daya Manusia: Untuk Bisnis Yang Kompetitif, Yogyakarta: Gajahmada University Press, 2011. 
Uno, H. B. Profesi kependidikan. Jakarta: Bumi Aksara, 2011.

Purwanto, Penerapan Kepemimpinan. Jakarta: Raja Grafindo Persada, 1997.

Rivai, Zainal, Veithzal dkk., Kepemimpinan dan Perilaku Organisasi, Jakarta: Raja Grafindo Persada, 2014.

Sumarno. Pengaruh Kepemimpinan Kepala Sekolah dan Profesionalisme Guru Terhadap Kinerja Guru Sekolah Dasar Negeri di Kecamatan Paguyangan Kabupaten Brebes. Tesis. (Semarang: Universitas Negeri Semarang, 2009.

Supardi. Kinerja Guru. Jakarta: Raja Grafindo Persada, 2013.

Sugiyono, Metode Penelitian Kuantitatif, Kualitatif, dan Kombinasi (Mixed Methods), Bandung: Alfabeta, 2012 Metode Penelitian Pendidikan, Bandung: Alfabeta, 2013. Metode Penelitian Administrasi, Bandung: Alfabeta, 2014.

Tim Dosen Administrasi Pendidikan Universitas Pensisikan Indonesia, Manajemen Pendidikan Bandung: Alfabeta, 2009.

Wahyudi, I., Mengejar Profesionalisme Guru, Jakarta: Prestasi Pustaka, 2012.

Wahjosumidjo, Kepemimpinan Kepala Sekolah Tinjauan Teoritik dan Permasalahannya, Jakarta: Raja Grafindo Persada, 2010. 